\title{
A stringent response-defective Bradyrhizobium diazoefficiens mutant elicits early plant defense and modifies autoregulation of nodulation in soybean
}

\author{
Julieta Pérez-Giménez ${ }^{1}$, Esteban Iturralde ${ }^{1}$, Gonzalo Torres-Tejerizo ${ }^{1}$, Juan Quelas ${ }^{1}$, \\ Elizaveta $\mathrm{Krol}^{2}$, Cecilia Borassi ${ }^{3}$, Anke Becker ${ }^{4}$, José Estevez ${ }^{5}$, and Aníbal Lodeiro ${ }^{1}$ \\ ${ }^{1}$ Universidad Nacional de la Plata \\ ${ }^{2}$ University of Marburg Centre of Synthetic Microbiology \\ ${ }^{3}$ Fundación Instituto Leloir \\ ${ }^{4}$ Philipps University of Marburg \\ ${ }^{5}$ Fundacion Instituto Leloir
}

July 28, 2020

\begin{abstract}
When subjected to nutritional stress, bacteria modify their amino acid metabolism and cell division activities by means of the stringent response, which is controlled by the Rsh protein in alphaproteobacteria. Although nutritional stress is common for rhizobia while infecting legume roots, the stringent response was scarcely studied in this group of soil bacteria. In this report, we obtained a mutant in the rsh gene of Bradyrhizobium diazoefficiens, the $\mathrm{N}_{2}$-fixing symbiont of soybean. This mutant was defective for type-3-secretion system induction, plant-defense suppression at early root infection, and competition for nodulation. Furthermore, the mutant produced smaller nodules, although with normal morphology, which lead to lower plant biomass production. The autoregulation of nodulation in $\mathrm{N}$-free condition was compromised in plants inoculated with the mutant, but it nodulated plants in the presence of $10 \mathrm{mM} \mathrm{NH}_{4} \mathrm{NO}_{3}$, a combined-N concentration inhibiting nodulation. The rsh mutant released more auxin to the culture supernatant than the wild-type, which might in part explain its symbiotic behavior in the presence of combined-N. These results indicate that B. diazoefficiens stringent response integrates into the plant defense suppression and autoregulation of nodulation circuits in soybean, perhaps mediated by the type-3-secretion system.
\end{abstract}

A stringent response-defective Bradyrhizobium diazoefficiens mutant elicits early plant defense and modifies autoregulation of nodulation in soybean ${ }^{\S}$

Running Head: Stringent response and regulation of nodulation

Julieta Pérez-Giménez ${ }^{1}$, Esteban T. Iturralde ${ }^{1}$, Gonzalo Torres-Tejerizo ${ }^{1}$, Juan Ignacio Quelas $^{1}$, Elizaveta Krol ${ }^{2}$, Cecilia Borassi ${ }^{3}$, Anke Becker ${ }^{2}$, José M. Estevez ${ }^{3,4}$, Aníbal R. Lodeiro $^{1,5 *}$

${ }^{1}$ IBBM, Facultad de Ciencias Exactas. CCT-La Plata CONICET y Universidad Nacional de La Plata. La Plata, Argentina

${ }^{2}$ Center for Synthetic Microbiology (SYNMIKRO); Department of Biology, Philipps-Universität Marburg, Germany

${ }^{3}$ Fundación Instituto Leloir, Instituto de Investigaciones Bioquímicas de Buenos Aires-CONICET, Buenos Aires, Argentina 
${ }^{4}$ Centro de Biotecnología Vegetal, Facultad de Ciencias de la Vida, Universidad Andrés Bello and Millennium Institute for Integrative Biology (iBio), Santiago, Chile

${ }^{5}$ Laboratorio de Genética, Facultad de Ciencias Agrarias y Forestales, Universidad Nacional de La Plata. La Plata, Argentina

*Corresponding author.lodeiro@biol.unlp.edu.ar

$\S$ To Federico Sánchez, our friend and teacher, who was an inexhaustible source of inspiration for this work.

Funding ANPCyT (PICT2017-2456 to ARL, PICT2016-0604 to JPG and PICT2017-0066 to JME), CONICET PIP 11220150100700CO to JPG, ICGEB CRP/ARG16-03, and Instituto Milenio iBio - Iniciativa Científica Milenio, MINECON to JME, and SPP 1879 - BE 2121/8-2 (DFG) to AB.

\begin{abstract}
When subjected to nutritional stress, bacteria modify their amino acid metabolism and cell division activities by means of the stringent response, which is controlled by the Rsh protein in alphaproteobacteria. Although nutritional stress is common for rhizobia while infecting legume roots, the stringent response was scarcely studied in this group of soil bacteria. In this report, we obtained a mutant in the rsh gene of Bradyrhizobium diazoefficiens, the $\mathrm{N}_{2}$-fixing symbiont of soybean. This mutant was defective for type-3secretion system induction, plant-defense suppression at early root infection, and competition for nodulation. Furthermore, the mutant produced smaller nodules, although with normal morphology, which lead to lower plant biomass production. The autoregulation of nodulation in $\mathrm{N}$-free condition was compromised in plants inoculated with the mutant, but it nodulated plants in the presence of $10 \mathrm{mM} \mathrm{NH}_{4} \mathrm{NO}_{3}$, a combined-N concentration inhibiting nodulation. The $r s h$ mutant released more auxin to the culture supernatant than the wild-type, which might in part explain its symbiotic behavior in the presence of combined-N. These results indicate that $B$. diazoefficiens stringent response integrates into the plant defense suppression and autoregulation of nodulation circuits in soybean, perhaps mediated by the type-3-secretion system.
\end{abstract}

Keywords stringent response; type-3-secretion system; plant defense; autoregulation of nodulation.

Acknowledgments JPG, GTT, JIQ, JME, and ARL are members of the Scientific Research Career of CONICET. ETI is a post-doctoral fellow of CONICET. The authors are grateful to Paula Gimenez, Silvana Tongiani, Claudio Mazo and Abel Bortolameotti for technical assistance and to Susana Jurado from the UNLP Microscopy Service for help with transmission electron microscopy.

A stringent response-defective Bradyrhizobium diazoefficiens mutant elicits early plant defense and modifies autoregulation of nodulation in soybean $\mathrm{SS}$

Abstract When subjected to nutritional stress, bacteria modify their amino acid metabolism and cell division activities by means of the stringent response, which is controlled by the Rsh protein in alphaproteobacteria. Although nutritional stress is common for rhizobia while infecting legume roots, the stringent response was scarcely studied in this group of soil bacteria. In this report, we obtained a mutant in the rsh gene of Bradyrhizobium diazoefficiens, the $\mathrm{N}_{2}$-fixing symbiont of soybean. This mutant was defective for type-3secretion system induction, plant-defense suppression at early root infection, and competition for nodulation. Furthermore, the mutant produced smaller nodules, although with normal morphology, which lead to lower plant biomass production. The autoregulation of nodulation in $\mathrm{N}$-free condition was compromised in plants

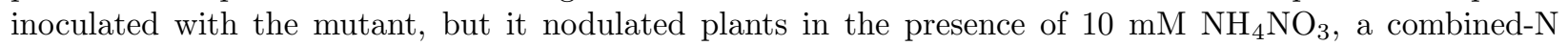
concentration inhibiting nodulation. The rsh mutant released more auxin to the culture supernatant than the wild-type, which might in part explain its symbiotic behavior in the presence of combined-N. These results indicate that $B$. diazoefficiens stringent response integrates into the plant defense suppression and autoregulation of nodulation circuits in soybean, perhaps mediated by the type-3-secretion system.

Keywords stringent response; type-3-secretion system; plant defense; autoregulation of nodulation.

\title{
1. INTRODUCTION
}


The symbiotic $\mathrm{N}_{2}$ fixation accounts for most of $\mathrm{N}$ inputs to the $\mathrm{N}$-cycle in terrestrial environments. This process is of agroecological importance because of its sustainability as biofertilization method in diverse legume crops, and thanks to its low cost and ease of application, it is extensively used worldwide (Terpolilli, Hood \& Poole, 2012). The symbiotic $\mathrm{N}_{2}$ fixation is carried out by the association of legume plants and a group of bacteria collectively known as rhizobia, which form and occupy nodules in the legume roots (Martinez-Romero, 2009). An important member of this group is Bradyrhizobium diazoefficiens, an alphaproteobacterium that fixes $\mathrm{N}_{2}$ in symbiosis with soybean, a pulse cropped in more than 200 million hectares mainly in the Americas.

Legume root nodulation is a multistep process that starts with the rhizobia-induced deformation of growing root hairs. This early manifestation is followed by an invagination of the root hair cell wall to produce a tubular structure towards root cortical cell layers. The rhizobia advance and proliferate within this tubular structure, known as the infection thread (IT), and finally they are released to the plant cell cytoplasm entrapped inside vesicles that bud into the root cortical cell layers where root nodules are growing (Goodchild \& Bergersen, 1966; Turgeon \& Bauer, 1985). In this way, the nodule-infected cells are filled with these rhizobia-containing vesicles known as symbiosomes, within which the rhizobia differentiate to bacteroids, express the nitrogenase complex, and fix $\mathrm{N}_{2}$. Because ITs are formed by invagination of the root hair cell wall (Fournier et al. , 2008), the IT interior is similar to the external root surface. Hence, during early infection the rhizobia-legume association might be harmful for both partners. On the one hand, the rhizobia behave like pathogens that proliferate at the expense of plant energy while they grow in the IT and during nodule cells invasion before $\mathrm{N}_{2}$ fixation starts. On the other hand, the plant releases antifungal and antibacterial substances, and provokes osmotic, nutritional and oxidative stresses into the IT (Brechenmacher et al. , 2010). In this scenario, unless both partners evolved mechanisms to cope with this mutual unkindness, the rhizobia-legume symbiosis would be rapidly doomed. However, the rhizobia are able to modulate the plant-defense reaction and the plant, in turn, may recognize the rhizobia as beneficial partners even before the symbiotic $\mathrm{N}_{2}$-fixation is activated (Gourion, Berrabah, Ratet \& Stacey, 2015). As part of this mutual adaptation, rhizobia adjust their metabolism in response to the stress conditions prevailing in the IT to preserve viability while gaining access to the inside of the developing root nodule.

Bacteria respond to these kinds of stresses using various transcriptionally-regulated systems, being the stringent response among the most important (Meury, 1988; Okada Y., Makino, Tobe, Okada N. \& Yamazaki, 2002; Pezzoni, Pizarro \& Costa, 2012; Potamitou, Neubauer, Holmgren, \& Vlamis-Gardikas, 2002; Rallu, Gruss \& Maguin, 1996; Wells \& Gaynor, 2006). The stringent response is a pleiotropic adaptation of bacteria to stressful and starving conditions, involving changes in translation and transcription rates, cell cycle control, and DNA repair (for review, see Ronneau \& Hallez, 2019). This response is triggered by accumulation of the second messenger alarmones guanosine 5'-diphosphate 3'-diphosphate (ppGpp) and guanosine 5'-triphosphate 3'-diphosphate (pppGpp), collectively known as (p)ppGpp, and was thoroughly studied inEscherichia coli . In response to stressing or starvation stimuli, (p)ppGpp is synthesized from GTP by the RelA GTP pyrophosphokinase and, after the normal conditions are restored, the alarmone is degraded by the bifunctional SpoT protein, which has both pyrophosphokinase and phosphodiesterase activities. Hence, the timing and magnitude of the response depends on the different steady-state levels of (p)ppGpp inside the cell at the particular conditions encountered. In alphaproteobacteria like $B$. diazoefficiens these roles are fulfilled by a bifunctional enzyme called Rsh (from $R$ elA- $S$ poT $H$ omologous).

Accumulation of (p)ppGpp in response to C- and N-starvation was reported decades ago in rhizobia (Belitsky \& Kari, 1982; Howorth \& England, 1999). However, the possible involvement of the stringent response in legume root infection and nodulation was recently studied only inEnsifer meliloti and Rhizobium etli . Nodulation and $\mathrm{N}_{2}$-fixation of Medicago sativa plants inoculated with E. meliloti relA or $d k s A$ mutants unable to trigger the stringent response are severely affected (Wells \& Long, 2002; Wippel \& Long, 2016; 2019). However, the relA E. melilotimutant nodulates $M$. truncatula, although $\mathrm{N}_{2}$-fixation remains altered (Wippel \& Long, 2019). Likewise, $R$. etli relA mutants produce small nodules with bacteroids devoid of polyhydroxybutyrate in Phaseouls vulgaris, and accordingly, the $\mathrm{N}_{2}$-fixation activity is substantially diminished in this plant (Calderon-Flores et al. , 2005; Moris et al ., 2005). In agreement with these results, nifA and rpoN, which are main regulators of symbiotic genes, were reported as part of the relA 
regulon in these rhizobial species (Krol \& Becker, 2011; Moris et al. , 2005).

B. diazoefficiens is a slow-growing rhizobial species distantly related to the above-mentioned fast-growing rhizobia. Therefore, to better understand the role of stringent response in the rhizobia-legume interaction, in this study we mutated the $r s h$ homolog of theB. diazoefficiens type-strain USDA 110 and investigated its effects on the regulation of plant defense and nodulation in soybean.

\section{MATERIALS AND METHODS}

\subsection{Bacterial strains and culture conditions.}

B. diazoefficiens was grown at $28 \mathrm{degC}$ in a rotary shaker at $180 \mathrm{rpm}$ in liquid peptone-salts-yeast extract medium (PSY; Regensburger \& Hennecke, 1983). The biomass was measured by optical density at $500 \mathrm{~nm}$ $\left(\mathrm{OD}_{500}\right)$ and, the number of viable bacteria was determined by counting the number of colony-forming units (CFU) on yeast extract-mannitol agar (YMA) plates (Vincent, 1970). Escherichia coli was grown in LuriaBertani (LB) medium at $37 \mathrm{degC}$. Media were supplemented with antibiotics at the following concentrations: for E. coli , gentamycin (Gm) $10 \mu \mathrm{g} \cdot \mathrm{ml}^{-1}$, kanamycin (Km) $25 \mu \mathrm{g} \cdot \mathrm{ml}^{-1}$ and tetracycline (Tc) $20 \mu \mathrm{g} \cdot \mathrm{ml}^{-1}$; for B. diazoefficiens, chloramphenicol (Cm) $20 \mu \mathrm{g} \cdot \mathrm{ml}^{-1}, \mathrm{Km} 150 \mu \mathrm{g} \cdot \mathrm{ml}^{-1}$ and Tc $100 \mu \mathrm{g} \cdot \mathrm{ml}^{-1}$.

\subsection{DNA manipulation.}

Standard protocols were used for DNA manipulations (Sambrook \& Russel, 2001). To obtain de rsh ::Km insertional mutant, a central region of 1616 bp was amplified by PCR with Pfx polymerase (Invitrogen) using the primers $r s h 1 \mathrm{Fw}$ and $r s h 2 \mathrm{Rv}$ (Table S1). The PCR cycling was started at $94^{\circ} \mathrm{C} 3$ min, followed by 35 cycles at $94^{\circ} \mathrm{C} 20 \mathrm{~s}, 56^{\circ} \mathrm{C} 20 \mathrm{~s}$, and $68^{\circ} \mathrm{C} 2 \mathrm{~min}$, and a final elongation step at $68^{\circ} \mathrm{C} 4 \mathrm{~min}$. The fragment was cloned into a previously SmaI -digested pG18mob2 (Schäfer et al ., 1994). The resulting plasmid was named pG18mob2::rsh . The construction was confirmed by sequencing. After that, the Km-resistance cassette was obtained as a SalIfragment from the pUC4K (Vieira \& Messing, 1982) and cloned into theXhoI -digested pG18mob2:: rsh. The latter plasmid was called pG18mob2::rsh ::Km and was introduced by conjugation into B. diazoefficiens USDA110 to generate the $r s h:: \mathrm{Km}$ insertional mutant. To assess the correct integration by double crossing-over intorsh, PCR reactions were carried out with primers rsh -compl-Fw and KmR, and $\mathrm{KmF}$ and $r s h$-compl-Rv (The PCR products evaluated are shown in Figure 1B). Once the correctness of the integration was confirmed, the $r s h$ ::Km strain was named LP 5065.

Plasmids transfer to B. diazoefficiens was carried out by conjugation using E. coli S17-1 as donor (Simon, Priefer \& Pühler, 1983). Matings were made in PSY.

\section{3 (p)ppGpp extraction and determination}

The procedure described by Krol \& Becker (2011) was adapted to B. diazoefficiens. Briefly, late-exponential PSY-cultures were centrifuged at $4,200 \times g$ for $10 \mathrm{~min}$ at $4{ }^{\circ} \mathrm{C}$. Each cell pellet was separated and resuspended in the same volume with 3-(N-morpholino)propanesulfonic acid (MOPS) or PSY to generate starving or control conditions, respectively. The incubation continued in the same conditions for an additional 24-h after which the nucleotide was extracted with $4 \mathrm{M}$ formic acid and five freeze-thaw cycles. Then, samples were incubated $30 \mathrm{~min}$ on ice, centrifuged at $15,000 \times \mathrm{g}$ for $10 \mathrm{~min}$ at $4{ }^{\circ} \mathrm{C}$ and the supernatants were filtered. Finally, the amount of (p)ppGpp was determined by anion exchange chromatography on Mono Q 5/50 GL column as described (Traxler et al ., 2008).

\subsection{Plants assays}

Glycine max soybean seeds cv. Williams were surface-sterilized and germinated as previously described (López-García, Vázquez, Favelukes \& Lodeiro, 2001). Then, each germinated seedling was planted in 650 $\mathrm{ml}$ pots containing sterile perlite:sand (2:1) watered with $250 \mathrm{ml}$ sterile modified Fåhraeus solution (MFS; Lodeiro, González, Hernández, Balagué \& Favelukes, 2000). To inoculate the plants, bacterial colonies from YMA were diluted in $1 \mathrm{ml}$ sterile MFS and deposited onto each seedling. Control plants were inoculated with $1 \mathrm{ml}$ of sterile MFS without bacteria. Plants were grown for 21 days in a plant growth chamber at 26 ${ }^{\circ} \mathrm{C} / 18{ }^{\circ} \mathrm{C}$ day $/$ night temperature, and a photoperiod of $16 \mathrm{~h}$. The plants were watered twice per week (once 
with sterile MFS and the other with sterile distilled water). To observe the effects of combined N, MFS was supplemented with $10 \mathrm{mM} \mathrm{NH} \mathrm{NO}_{3}$.

To estimate the ureide contents in leaves, 10-mg samples of dry leaf tissue were homogenized in $1 \mathrm{ml} 0.2$ $\mathrm{N} \mathrm{NaOH}$ during $30 \mathrm{~min}$ at $100{ }^{\circ} \mathrm{C}$. Then, homogenates were centrifuged at $10,000 \times \mathrm{g}$ for $10 \mathrm{~min}$, and the ureide concentrations were quantified in supernatants as the phenylhydrazone of glyoxylate (Vogels \& van der Drift, 1970).

To assess plant growth, the plants were grown for 35 days in the same conditions, and shoots were cut, dried to a constant weight in an oven at $60{ }^{\circ} \mathrm{C}$ for 5 days, and weighed individually. Statistical analyses were carried out by analysis of variance with a significance level of $p<0.05$.

To evaluate competition for nodule occupancy, soybean plants were co-inoculated with a mixture of $B$. diazoefficiens USDA 110 and LP 5065 in a 1:1 proportion. For this purpose, pots were inoculated by watering with MFS containing $110^{6} \mathrm{UFC} \mathrm{m}^{-1}$ of each strain. 21 days after inoculation, all nodules were collected and superficially sterilized with $\mathrm{NaHClO} 10 \%$ (vol/vol) and washed several times with sterile distilled water. The nodules were macerated and chopped on YEM plates with antibiotics, $\mathrm{Cm}$ or $\mathrm{Cm} \mathrm{Km}$, to determine the occupation of each strain. In this way, the nodule extracts that grew in the presence of $\mathrm{Cm}$ and $\mathrm{Km}$ indicated the presence of LP 5065, while those sensitive to Km corresponded to nodule extracts in which LP 5065 was absent. We considered valid those assays in which $100 \%$ of the nodules from plants inoculated with single strains were occupied by the corresponding strains, and at the same time no nodules were formed in the uninoculated controls. For statistical analysis, these values were transformed to the arcsin root square, and analysis of variance was done with the transformed values, employing a significance level of $p<0.05$.

\subsection{RNA extractions and Quantification of Transcript Levels by RT-qPCR}

For RNA extraction from roots, germinated seeds were grown in liquid MFS with the same light and temperature conditions described above. Roots were cut, frozen in liquid $\mathrm{N}_{2}$, and RNA was extracted with TRIzol (Life Technologies) following the manufacturer's instructions. For bacterial RNA extraction, B. diazoefficienslate-exponential PSY liquid cultures were induced with genistein dissolved in methanol at a final concentration of $2 \mu \mathrm{M}$ or the same volume of methanol as control. After 48 hours of growth in the same conditions, cells were collected and RNA extractions were performed as described (Mongiardini, Quelas, Dardis, Althabegoiti \& Lodeiro, 2017).

For retrotranscribed quantitative polymerase chain reaction (RT-qPCR) from both plant and bacterial extracts, two-step cDNA was obtained using a M-MLV reverse transcriptase (Invitrogen) and quantified by qPCR using iQ SYBR green Supermix (Bio-Rad, USA), according to the manufacturer's instructions. Genespecific primers used in RT-qPCR reactions are listed in Table S1. qPCRs were performed in a qTower 2.0 (Analytik Jena). Normalized expression values were calculated as the ratio between the relative quantities of the gene of interest (GOI) and the relative quantities of the house-keeping genes indicated in the figures' captions.

\section{6 cytROS determinations}

Two-day old soybean seedlings were inoculated with $110^{6} \mathrm{UFC} \mathrm{ml}^{-1}$ B. diazoefficiens wild type or rsh mutant in MFS, or in MFS alone as control. After 12 or $48 \mathrm{~h}$, roots were incubated with $500 \mu \mathrm{M} 2^{\prime}, 7^{\prime}-$ dichlorodihydrofluorescein diacetate for $30 \mathrm{~min}$ in darkness at room temperature. Images were obtained by using a Zeiss Imager A2 epifluorescence microscope. The objective used was 10X, NA=0.3 and the exposure time was 80-500 ms. The images were analyzed using the ImageJ program. To measure cytosolic ROS levels, a circular region of interest (ROI, $r=2.5 \mu \mathrm{m}$ ) was selected at the root tip and the average of the intensities of the pixels included in the ROI was calculated. The reported values are the mean \pm standard error.

\subsection{IAA determinations}

IAA was measured as described by Gravel, Antoun \& Tweddell (2007).B. diazoefficiens was grown in PSY liquid medium for 7 days at $28^{\circ} \mathrm{C}$ and then centrifuged at $13,000 \times \mathrm{g}$ for $3 \mathrm{~min}$. The Salkowski reagent was 
added to the supernatant (Gordon \& Weber, 1951) and left in the dark for 20 minutes. After this incubation time, auxin concentrations were estimated by optical density at $535 \mathrm{~nm}$ against a calibration curve made with known IAA concentrations.

\subsection{Microscopy}

These analyses were performed at the Microscopy Service of Facultad de Ciencias Veterinarias (UNLP, Argentina) as previously described (Quelaset al ., 2010). Briefly, nodules were transversally cut in halves and fixed in $2 \%$ (vol/vol) glutaraldehyde. Samples were dehydrated, infiltrated with epoxy resin, and sectioned. For optical microscopy, glutaraldehyde-fixed $2-\mu \mathrm{m}$-thick nodule sections were dried onto glass slides, stained with a saturated solution of toluidine blue, and analyzed using a Nikon Eclipse E200 microscope (Melville, $\mathrm{NY}$ ). For transmission electron microscopy, ultrathin nodule sections were stained with 0.5 to $1 \%\left(\mathrm{wt} \mathrm{vol}^{-1}\right.$ ) uranyl acetate for $10 \mathrm{~min}$ and $1 \%\left(\mathrm{wt} \mathrm{vol}^{-1}\right)$ lead citrate for $5 \mathrm{~min}$, washed in distilled water, and air dried. Then the cuts were analyzed with a JEM 1200 EX (JEOL, Japan Electron Optics Laboratory Co., Ltd.). Micrographs were obtained with an ES500W Erlangshen charge-coupled device camera (Gatan Inc., Pleasanton, CA).

\section{RESULTS}

\subsection{The B. diazoefficiens rsh mutant is impaired for survival under stress conditions}

The locus bll5065 of B. diazoefficiens USDA 110 is annotated asrelA(http://genome.annotation.jp/rhizobase/Bradyrhizobium accessed on Aug 16, 2019). Furthermore, no other paralogs were found in this genome, whereby we considered that this ORF is actually anrsh gene. Moreover, this gene lies in a genomic context similar to known examples of relA, spoT or rsh in other species (Figure S1) and also possesses a similar domains structure (Figure S2). Its gene product is predicted with high score as a bifunctional (p)ppGpp synthetase II/guanosine 3',5'bis pyrophosphatase (Figure 1A). A mutant was obtained by inserting a Km-resistance cassette in the middle of the bll5065 coding sequence (Figure 1B). This insertional mutant was named LP 5065 , and hereafter it will be referred to as rsh mutant.

To compare the effect of the mutation, the wild-type and the rshmutant were cultured for $24 \mathrm{~h}$ in PSY rich medium, or in MOPS buffer (hereafter referred to as starving conditions). Then, (p)ppGpp was extracted from these cultures and measured by anion exchange chromatography. The signal obtained with the wild-type under starving conditions was about $2 \mathrm{nM}$ in the culture extract, indicating that $B$. diazoefficiens produced very small quantities of (p)ppGpp than other well-characterized species in which the alarmone was measured with the same strategy (Krol and Becker, 2011). Nevertheless, (p)ppGpp could be detected neither in the wild-type cultured in rich medium nor in thersh mutant incubated either in starving or in rich media. Growth kinetics and total biomass production in rich medium were similar between the wild-type and the mutant, indicating that the rshmutation did not alter growth under these conditions (Figure 2A). However, bacterial survival under starving conditions was compromised in the rsh mutant (Figure 2B). Taken together, the above results confirmed that the locus bll5065 encodes an Rsh protein, which is involved in the stringent response of $B$. diazoefficiens to starvation.

\subsection{The $r s h$ mutation precludes induction of the type-3 secretion system (T3SS)}

Among the various cellular processes affected by the stringent response is induction of the type-3 secretion system (T3SS) (Ancona et al ., 2015). Previously, it was shown that in B. diazoefficiensthe T3SS is inducible by genistein, a flavonoid released by soybean roots and inducing nodulation genes (Krause, Doerfel \& Göttfert, 2002). To observe if there is a link between the stringent response and T3SS in this bacterium, the expressions of the T3SS structural gene rhcJand T3SS regulator ttsI were measured by RT-qPCR in the wild-type or the rsh mutant incubated under starving conditions. As shown in Table 1, both genes were strongly induced by genistein in the wild-type, but there was no response in the $r s h$ mutant.

\subsection{The $r s h$ mutant elicits a stronger early plant-defense response}

During rhizobial infection of soybean roots the systemic acquired resistance (SAR) is triggered at early 
stages and later it is suppressed (Jiménez-Guerrero et al ., 2015). Given that the $r$ sh mutant was unable to induce the T3SS in response to genistein, it may be expected that this mutant has some defect in SAR suppression. SAR is characterized in soybean by the expression of the PATHOGENESIS-RELATED 1 (GmPR1) gene. Therefore, the expression of the GmPR1 SAR marker was measured by RT-qPCR. As shown in Figure 3A, the induction of $G m P R 1$ at $12 \mathrm{~h}$ after inoculation with the $r s h$ mutant was significantly higher than in plants inoculated with the wild-type. Later, at $48 \mathrm{~h}$, there was no statistically significant difference in $G m P R 1$ transcripts accumulation between both strains, indicating that $r s h$ was required to inhibit GmPR1 transcription during the first $12 \mathrm{~h}$ of rhizobia-plant interaction. Another SAR marker is the production of cytoplasmic reactive oxygen species (cytROS). In agreement with the changes observed in GmPR1 expression levels, the cytROS levels in the tip of root hair cells where polar growth is highly active, were significantly higher at $12 \mathrm{~h}$ in plants inoculated with the $r s h$ mutant than in plants inoculated with the wild-type, without difference at $48 \mathrm{~h}$ (Figure 3B). Therefore, these results suggest that early suppression of plant-defense responses (12 h after inoculation) was compromised in the rsh mutant.

\subsection{The rsh mutant alters autoregulation of nodulation}

Autoregulation of nodulation (AON) evolved to avoid excessive photosynthates expenditures in nodulation when alternative $\mathrm{N}$-sources are available, or when a number of nodules enough to satisfy plant $\mathrm{N}$-requirements was reached (Nishida \& Suzaki, 2018). These autoregulatory responses are mediated by systemic signals where a class of peptides, named CLAVATA/ENDOSPERM-SURROUNDING REGION (CLE) peptides, plays the main role. In soybean, monitoring of combined $\mathrm{N}$ and nodules quantity is exerted by related CLE peptides, named NITROGEN-INDUCED CLE $(G m N I C$ ) for the combined N response, and RHIZOBIA-INDUCED CLE 1 and 2 (GmRIC1 and GmRIC2 ) for the nodules quantity response (Reid, Ferguson \& Gresshoff, 2011). As the rsh mutant recognition was, in somehow, different, the question arose as to how this mutant could deal with AON. Thus, we measured the levels of those three markers.

Soybean plants inoculated with the wild-type or the $r s h$ mutant were cultivated during 72 hours in presence or absence of $10 \mathrm{mM} \mathrm{NH}_{4} \mathrm{NO}_{3}$, a combined-N concentration that inhibits nodulation. Then, the levels of GmNIC , GmRIC1, and GmRIC2 transcripts were measured in plant roots by RT-qPCR. As previously reported by Reid et al. (2011), the GmNIC transcript accumulated in plants cultivated in the presence of $\mathrm{NH}_{4} \mathrm{NO}_{3}$. Interestingly, the GmNIC transcript was more abundant in plants inoculated with the rshmutant than with the wild-type, irrespective of the presence or absence of $\mathrm{NH}_{4} \mathrm{NO}_{3}$ (Table 2). On the contrary, GmRIC1 and GmRIC2 were downregulated by the presence of $10 \mathrm{mM} \mathrm{NH}_{4} \mathrm{NO}_{3}$, but in its absence, both GmRIC1 and GmRIC2 were significantly more expressed in plants inoculated with the $r s h$ mutant than with the wild-type (Table 2). Furthermore, in the presence of $10 \mathrm{mM} \mathrm{NH}_{4} \mathrm{NO}_{3}$ there were no statistically significant differences in expression of GmRIC1 or GmRIC2 between the rsh mutant and the wild-type.

\subsection{The rsh mutant has diminished symbiotic capacity}

Higher levels of GmRIC1 and GmRIC2 as induced by thersh mutant in the absence of $\mathrm{NH}_{4} \mathrm{NO}_{3}$ may inhibit soybean nodulation (Reid et al. , 2011). Therefore, we studied the nodulation capacity of our B. diazoefficiens strains.

Soybean plants inoculated with the $r s h$ mutant produced 30 nodules per plant, similarly to the wild-type (Table 3 ). The nodules produced by the $r s h$ mutant were histologically normal and contained symbiosomes occupied by bacteroids, as the wild-type (Figure 4A, B, E, F) However, they were smaller than the wild-type (Table 3). In agreement with their low nodules biomass, the shoot dry weight of plants nodulated by the rsh mutant was intermediate between plants nodulated by the wild-type and uninoculated controls, but the ureide contents in leaves were similar (Table 3). These results suggest that nodulation and $\mathrm{N}_{2}$ fixation was somewhat compromised in the mutant, although not substantially inhibited.

When two different rhizobia genotypes are co-inoculated together on the same plant, both genotypes have to compete for root infection and nodules occupation. Thus, the proportion of nodules occupied by each genotype is a good indicator of its intrinsic infectivity and competitiveness during these early symbiotic processes (Pérez-Giménez, Quelas \& Lodeiro, 2011). When the $r s h$ mutant was co-inoculated with the wild- 
type in 1:1 proportion, only $26 \%$ of the nodules were occupied by the mutant (Table 3), indicating that intrinsic infectivity and competitiveness for nodulation were affected by the loss of stringent response.

\subsection{The rsh mutant nodulated in the presence of a high concentration of combined $\mathrm{N}$}

The lack of GmRIC1/2 transcripts overproduction in plants inoculated with the $r s h$ mutant when cultured in the presence of $10 \mathrm{mM} \mathrm{NH}_{4} \mathrm{NO}_{3}$ by difference with those cultured in the $\mathrm{N}$-free medium (Table 2) suggested that this mutation might alter the inhibitory effects of combined $\mathrm{N}$ on nodulation. To test this possibility, soybean plants were inoculated with the wild-type or the $r s h$ mutant and then cultured for 21 days with or without $10 \mathrm{mM} \mathrm{NH} \mathrm{NO}_{3}$. As expected, the plants inoculated with the wild-type produced normal nodules in the absence of the combined $\mathrm{N}$-source but produced only a few and small pseudonodules when cultured with $10 \mathrm{mM} \mathrm{NH}_{4} \mathrm{NO}_{3}$ (Figure 4C). Accordingly, when these nodules were observed at the transmission electron microscope, their ultrastructure showed cells with large vacuoles, and absence of rhizobia (Figure 4G). By contrast, in the plants inoculated with the rsh mutant, normal and red but small nodules were produced in the presence of $10 \mathrm{mM} \mathrm{NH}_{4} \mathrm{NO}_{3}$ (Figure 4D), which possessed symbiosomes with normal bacteroids (Figure $4 \mathrm{H})$.

\subsection{Higher production of extracellular auxins by the rshmutant}

Nodulation requires a certain balance of auxin/cytokinin ratio, as well as reduction of auxin transport (Caba, Centeno, Fernández, Gresshoff \& Ligero, 2000; Jin, Watt \& Mathesius, 2012; Ng et al ., 2015). To see whether the rsh mutant might exogenously produce auxin imbalances in the plants, we measured extracellular auxins produced by the wild-type and the $r s h$ mutant grown in culture medium. We observed that the $r s h$ mutant released significantly more amounts of auxins to the culture supernatant than the wild-type (Figure 5).

\section{DISCUSSION}

The IT seems a harsh environment for the rhizobia (Brechenmacheret al ., 2010). Therefore, we speculated that the stringent response should be active at this infection step, and that such activity might have a role in the control of plant response. Thus, in this report we compared the soybean responses to infection by either an $r$ shmutant or the wild-type.

We observed that, under starving conditions, the rsh mutant did not induce the expression of the T3SS regulator ttsI and therhcJ structural gene in the presence of genistein, in agreement with previous studies indicating that the (p)ppGpp alarmone is required for activation of the T3SS in Erwinia amylovora (Ancona et al ., 2015). Deletions in ttsI and rhcJ abolished T3SS secretion in B. diazoefficiens (Süss et al. , 2006; Tsukuiet al. , 2013). Hence, if the stringent response is triggered in the IT, it might promote the injection of Nop effectors (Staehelin \& Krishnan, 2015) into the root hair cell, which were reported as suppressors of early plant defense response (Jiménez-Guerrero et al ., 2015; López-Baena et al ., 2009). Accordingly, here we observed that the rsh mutant strongly induced the SAR markerGmPR1 in our soybean roots, in parallel with a transient increase in cytROS. In agreement with these results, a transient increase in cytROS at early infection of soybean by wild-type B. japonicumwas observed by Fernandez-Göbel et al - (2019). In addition to cytROS, SAR signaling is mediated also by nitric oxide (NO) and salicylic acid (SA) (Shine, Xiao, Kachroo P. \& Kachroo A., 2019). It is worth noting that NO increases transiently in Lotus japonicusroots soon after inoculation with its symbiont Mesorhizobium loti, with a kinetics similar to our observations of GmPR1induction (Nagata et al ., 2008). Moreover, endogenous reduction of SA levels obtained by overexpressing the bacterial salicylate hydroxylase coding gene $n a h G$ in hairy roots increased the number of root infections and nodule number in Lotus japonicus (Stacey, McAlvin, Kim, Olivares \& Soto, 2006). Taken together, these results suggest that stringent response is required to induce T3SS Nops injection into the root hair and suppress the transient SAR a few hours after inoculation (Figure 6).

During $\mathrm{N}_{2}$ fixation the plant incurs in an energetic cost to maintain nodules functioning. To avoid excessive proliferation of nodules, the plant exerts autoregulatory control through the CLE peptides GmRIC1 and GmRIC2 (Nishida \& Suzaki, 2018; Reidet al. , 2011), whose expression was increased by the rshmutant in the absence of combined-N (Table 2). It is tempting to speculate that Nops participate in inhibiting the 
induction of these CLE peptides, but up to now it is unclear whether such inhibition is carried out directly by these effectors in parallel with SAR suppression. Alternatively, a possible timeline of events triggered by the rshmutant might be an early accumulation of ROS and GmPR1 followed by SAR, which in turn induces GmRIC1 and GmRIC2 . In this scenario, SAR suppression by T3SS-delivered Nop effectors from the wildtype might lead to inhibition of GmRIC1 and GmRIC2induction, thus explaining the different kinetics of these processes (Figure 6). In addition, it was reported that GmRIC1 and GmRIC2 levels are modulated by Nod factors (NF), with participation of the transcription factor NODULE INCEPTION ( $G m N I N a$ ), a plant micro-RNA called MiR1/2c, and the transcriptional repressor NODULE NUMBER CONTROL 1 (GmNNC1 ) (Wanget al ., 2019). Nevertheless, in E. meliloti and R. etli cultured in the presence of flavonoid inducers, there were no differences in expression of nod genes or NF production between wild-type and rsh mutants (Calderón-Flores et al ., 2005; Wippel \& Long, 2019), and the same was observed for nodCexpression in $E$. meliloti between the wild-type and a $d k s A$ mutant (Wippel \& Long, 2016). Therefore, the observed increase of GmRIC1 and GmRIC2 expression might not be due to a direct effect of rsh mutation on NF production.

GmRIC1 and GmRIC2 are translocated and perceived in the shoot by the Glycine max NODULE AUTOREGULATION RECEPTOR KINASE (GmNARK ) (Searle et al ., 2003). Similarly, another CLE peptide, $G m N I C$, which is produced and translocated to the shoot in response to the presence of combined nitrogen, is also perceived by GmNARK. The NARK orthologous in L. japonicus is HYPERNODULATION ABERRANT ROOT FORMATION 1 (HAR1). After perception of such CLE peptides, LjHAR1 induces the synthesis of cytokinin, which is translocated as a shoot-derived signal to the roots, where it inhibits nodulation (Sasaki et al ., 2014). Therefore, the circuit of CLE-peptides, GmNARK and cytokinin might integrate the signals of excess infections or availability of combined nitrogen to negatively control the number of active nodules. In the present report we observed that, in the absence of combined $\mathrm{N}$, the expression of the three CLE peptides was higher in plants inoculated with the rsh mutant, while in the presence of combined nitrogen $G m N I C$ was strongly induced?both in plants inoculated with the rsh mutant and with the wildtype?but there were no responses of GmRIC1 or GmRIC2. Therefore, the stringent response seems to affect the part of AON related with rhizobial infections, but not the part related with combined nitrogen availability. Thus, the stringent response might be involved in perception of rhizobia by AON, possibly through Nops effectors, while combined nitrogen is sensed by AON through a different pathway, both pathways involving CLE peptides and joining at GmNARK (Figure 6).

In agreement with these observations, nodules size was reduced in plants inoculated with the rsh mutant, although their ultrastructure seemed normal. In addition, $\mathrm{N}_{2}$-fixation was somewhat affected, but not as strongly as previously observed in common beans inoculated with a $R$. etli $r s h$ mutant (Calderon-Floreset al ., 2005; Moris et al ., 2005). These results indicate that the effects of an rsh mutation in B. diazoefficienson soybean nodule morphology and function are not as severe as in $R$. etli on common bean nodules, despite both plants produce determinate nodules. This difference might be related to the low level of (p)ppGpp production in $B$. diazoefficiens. For the case of $E$. meliloti, nodulation was compromised in $M$. sativa but not in $M$. truncatula, although in this host, nodule cells infection and $\mathrm{N}_{2}$-fixation were lower with the rshmutant than with the wild-type (Wippel \& Long, 2019). In addition, ourB. diazoefficiens rsh mutant was intrinsically less competitive than the wild-type to occupy soybean nodules, indicating that, as observed in E. meliloti -M. sativa (Wippel \& Long, 2019), root infection might have been detracted.

The poor nodulation might be, at least in part, caused by increased plant defense response as well as by stronger nodulation repression by the AON response against the rsh mutant. However, it was surprising that the rsh mutant nodulated soybean plants cultivated with an inhibitory concentration of combined nitrogen. Although these nodules were scarce and small, they were red, and did possess infected cells with bacteroids inside normal symbiosomes (Figure 4D, H). This might suggest that, although initial infection was precluded by combined nitrogen as for the wild-type, the rshmutant bacteria that managed to travel all along ITs were successful in budding from ITs once the cortical cell layers were reached.

We observed that the rsh mutant secreted higher quantity of auxin to the surrounding medium. It is known that auxin synthesis and transport regulate root hair elongation (Velasquez, Barbez, Kleine-Vehn \& Estevez, 
2016), and local auxin accumulation is essential for nodule development (Liu, Zhang, Yang, Yu \& Wang, 2018). Therefore, these processes might be altered by the increased auxin production by thersh mutant. This hypothesis might be confirmed with an rshmutant unable to secrete auxins, together with in situ measures of auxin levels in the root infection zone.

Taken together, our results indicate that the stringent response of $B$. diazoefficiens is integrated into the circuits of regulation of plant defense and autoregulation of nodulation, with an impact on nodulation, plant biomass production, and response to the presence of combined nitrogen in the rhizosphere.

\section{ACKNOWLEDGMENTS}

This work was supported by ANPCyT (PICT2017-2456, PICT2016-0604, and PICT2017-0066), CONICET PIP 11220150100700CO, ICGEB CRP/ARG16-03, Instituto Milenio iBio - Iniciativa Cientifica Milenio, MINECON, and SPP 1879 - BE 2121/8-2 (DFG).

\section{CONFLICT OF INTERESTS}

The authors declare that there are no conflicts of interests.

\section{REFERENCES}

1. Ancona, V., Lee, J.H., Chatnaparat, T., Oh, J., Hong, J.I. \& Zhao, Y. (2015). The bacterial alarmone (p)ppGpp activates the type III secretion system in Erwinia amylovora. Journal of Bacteriology . doi: https://doi.org/10.1128/JB.02551-14.

2. Belitsky, B \& Kari, C. (1982). Absence of accumulation of ppGpp and RNA during amino acid starvation in Rhizobium meliloti .Journal of Biological Chemistry. 257(9), 4677-4679.

3. Brechenmacher, L., Lei, Z., Libault, M., Findley, S., Sugawara, M., Sadowsky, M.J., Sumner, L.W. \& Stacey, G. (2010). Soybean metabolites regulated in root hairs in response to the symbiotic bacteriumBradyrhizobium japonicum . Plant Physiolology . doi: https://doi.org/10.1104/pp.110.157800.

4. Caba, J.M., Centeno, M.L., Fernandez, B., Gresshoff, P.M. \& Ligero, F. (2000). Inoculation and nitrate alter phytohormone levels in soybean roots: differences between a supernodulating mutant and the wild type.Planta . https://doi.org/10.1007/s004250000265.

5. Calderon-Flores, A., Du Pont, G., Huerta-Saquero, A., Merchant-Larios, H., Servin-Gonzalez, L. \& Duran, S. (2005). The stringent response is required for amino acid and nitrate utilization, nod factor regulation, nodulation, and nitrogen fixation inRhizobium etli . Journal of Bacteriology . https://doi.org/10.1128/JB.187.15.5075-5083.2005.

6. Fernandez-Gobel, T.F., Deanna, R., Munoz, N.B., Robert, G., Asurmendi, S. \& Lascano, R. (2019). Redox systemic signaling and induced tolerance responses during soybean-Bradyrhizobium japonicum interaction: involvement of nod factor receptor and autoregulation of nodulation. Frontiers in Plant Science . https://doi.org/10.3389/fpls.2019.00141.

7. Fournier, J., Timmers, A.C., Sieberer, B.J., Jauneau, A., Chabaud, M. \& Barker, D.G. (2008). Mechanism of infection thread elongation in root hairs of Medicago truncatula and dynamic interplay with associated rhizobial colonization. Plant Physiology . https://doi.org/10.1104/pp.108.125674.

8. Goodchild, D.J. \& Bergersen, F.J. (1966). Electron microscopy of the infection and subsequent development of soybean nodule cells. Journal of Bacteriology . 92(1), 204-213.

9. Gordon, S.A. \& Weber, R.P. (1951). Colorimetric estimation of indoleacetic acid. Plant Physiology . https://doi.org/10.1104/pp.26.1.192.

10. Gourion, B., Berrabah, F., Ratet, P. \& Stacey, G. (2015).Rhizobium -legume symbioses: the crucial role of plant immunity. Trends in Plant Science. https://doi.org/10.1016/j.tplants.2014.11.008. 
11. Gravel, V., Antoun, H. \& Tweddell, R.J. (2007). Growth stimulation and fruit yield improvement of greenhouse tomato plants by inoculation with Pseudomonas putida or Trichoderma atroviride : possible role of indole acetic acid (IAA). Soil Biology and Biochemistry . https://doi.org/10.1016/j.soilbio.2007.02.015.

12. Howorth, S.M. \& England, R.R. (1999). Accumulation of ppGpp in symbiotic and free-living nitrogen-fixing bacteria following amino acid starvation. Archives of Microbiology . https://doi.org/10.1007/s002030050689.

13. Jimenez-Guerrero, I., Perez-Montano, F., Monreal, J.A., Preston, G.M., Fones, H., Vioque, B., Ollero, F.J. \& Lopez-Baena, F.J. (2015). The Sinorhizobium (Ensifer) fredii HH103 type 3 secretion system suppresses early defense responses to effectively nodulate soybean.Molecular Plant Microbe Interactions . https://doi.org/10.1094/MPMI-01-15-0020-R.

14. Jin, J., Watt, M. \& Mathesius, U. (2012). The autoregulation geneSUNN mediates changes in root organ formation in response to nitrogen through alteration of shoot-to-root auxin transport.Plant Physiology . https://doi.org/10.1104/pp.112.194993.

15. Krause, A., Doerfel, A. \& Gottfert, M. (2002). Mutational and transcriptional analysis of the type III secretion system of Bradyrhizobium japonicum . Molecular Plant Microbe Interactions . https://doi.org/DOI: 10.1094/MPMI.2002.15.12.1228.

16. Krol, E. \& Becker, A. (2011). ppGpp in Sinorhizobium meliloti : biosynthesis in response to sudden nutritional downshifts and modulation of the transcriptome. Molecular Microbiology . https://doi.org/10.1111/j.1365-2958.2011.07752.x.

17. Liu, H., Zhang, C., Yang, J., Yu, N. \& Wang, E. (2018). Hormone modulation of legume-rhizobial symbiosis. Journal of Integrative Plant Biology. https://doi.org/10.1111/jipb.12653.

18. Lodeiro, A.R., Gonzalez, P., Hernandez, A., Balague, L.J. \& Favelukes, G (2000). Comparison of drought tolerance in nitrogen-fixing and inorganic nitrogen-grown common beans. Plant Science.https://doi.org/10.1016/S0168-9452(99)00246-0.

19. Lopez-Baena, F.J., Monreal, J.A., Perez-Montano, F., Guasch-Vidal. B., Bellogin. R.A., Vinardell, J.M. \& Ollero, F.J. (2009). The absence of Nops secretion in Sinorhizobium fredii HH103 increasesGmPR1 expression in Williams soybean. Molecular Plant Microbe Interactions . https://doi.org/10.1094/MPMI-2211-1445.

20. Lopez-Garcia, S.L., Vazquez T.E., Favelukes G. \& Lodeiro A.R. (2001). Improved soybean root association of N-starvedBradyrhizobium japonicum . Journal of Bacterioogy . https://doi.org/10.1128/JB.183.24.7241-7252.2001.

21. Martinez-Romero, E. (2009). Coevolution in Rhizobium -legume symbiosis? DNA and Cell Biology. https://doi.org/10.1089/dna.2009.0863.

22. Meury, J. (1988). Glycine betaine reverses the effects of osmotic stress on DNA replication and cellular division in Escherichia coli . Archives of Microbiology . https://doi.org/10.1007/bf00422010.

23. Mongiardini, E.J., Quelas, J.I., Dardis, C., Althabegoiti, M.J. \& Lodeiro, A.R. (2017). Transcriptional control of the lateral-flagellar genes of Bradyrhizobium diazoefficiens . Journal of Bacteriology . https://doi.org/10.1128/JB.00253-17.

24. Moris, M., Braeken, K., Schoeters, E., Verreth, C., Beullens, S., Vanderleyden, J. \& Michiels, J. (2005). Effective symbiosis betweenRhizobium etli and Phaseolus vulgaris requires the alarmone ppGpp. Journal of Bacteriology . https://doi.org/10.1128/JB.187.15.5460-5469.2005.

25. Nagata, M., Murakami, E., Shimoda, Y., Shimoda-Sasakura, F., Kucho, K., Suzuki, A., Abe, M., Higashi, S. \& Uchiumi, T. (2008). Expression of a class 1 hemoglobin gene and production of nitric oxide 
in response to symbiotic and pathogenic bacteria in Lotus japonicus . Molecular Plant Microbe Interactions . https://doi.org/10.1094/MPMI-21-9-1175.

26. Ng, J.L., Hassan, S., Truong, T.T., Hocart, C.H., Laffont, C., Frugier, F. \& Mathesius, U. (2015). Flavonoids and auxin transport inhibitors rescue symbiotic nodulation in the Medicago truncatulacytokinin perception mutant cre1 . Plant Cell . https://doi.org/10.1105/tpc.15.00231.

27. Nishida, H. \& Suzaki, T. (2018). Two negative regulatory systems of root nodule symbiosis - how are symbiotic benefits and costs balanced? Plant and Cell Physiology . https://doi.org/10.1093/pcp/pcy102.

28. Okada, Y., Makino, S., Tobe, T., Okada, N. \& Yamazaki, S. (2002). Cloning of rel from Listeria monocytogenes as an osmotolerance involvement gene. Applied and Environmental Microbiology . https://doi.org/10.1128/aem.68.4.1541-1547.2002.

29. Perez-Gimenez, J., Quelas, J.I. \& Lodeiro, A.R. (2011). Competition for nodulation. In Soybean/Book 3. Physiology and Biochemistry. (ed. Hany A. El-Shemy). pp. 139-166 InTech Open Access Publisher, Rijeka (Croatia). https://doi.org/10.5772/18034.

30. Pezzoni. M., Pizarro, R.A. \& Costa, C.S. (2012). Protective effect of low UVA irradiation against the action of lethal UVA onPseudomonas aeruginosa : role of the relA gene. Journal of Photochemistry and Photobiology B . https://doi.org/10.1016/j.jphotobiol.2012.08.011.

31. Potamitou, A., Neubauer, P., Holmgren, A. \& Vlamis-Gardikas, A. (2002). Expression of Escherichia coli glutaredoxin 2 is mainly regulated by ppGpp and sigmaS. Journal of Biological Chemistry . https://doi.org/10.1074/jbc.M201306200.

32. Quelas, J.I., Mongiardini, E.J., Casabuono, A., Lopez-Garcia, S.L., Althabegoiti, M.J., Covelli, J.M., Perez-Gimenez, J., Couto, A. \& Lodeiro, A.R. (2010). Lack of galactose or galacturonic acid inBradyrhizobium japonicum USDA 110 exopolysaccharide leads to different symbiotic responses in soybean. Molecular Plant-Microbe Interactions . https://doi.org/10.1094/MPMI-05-10-0122.

33. Rallu, F., Gruss, A. \& Maguin E. (1996). Lactococcus lactisand stress. Antonie Van Leeuwenhoek . https://doi.org/10.1007/bf00395935.

34. Reid, D.E., Ferguson, B.J. \& Gresshoff, P.M. (2011). Inoculation- and nitrate-induced CLE peptides of soybean control NARK-dependent nodule formation. Molecular Plant Microbe Interactions . https://doi.org/10.1094/MPMI-09-10-0207.

35. Regensburger, B., \& Hennecke, H. (1983). RNA polymerase fromRhizobium japonicum . Archives of Microbiology . https://doi.org/10.1007/BF00408017.

36. Ronneau, S. \& Hallez, R. (2019). Make and break the alarmone: regulation of (p)ppGpp synthetase/hydrolase enzymes in bacteria.FEMS Microbiology Reviews . https://doi.org/10.1093/femsre/fuz009.

37. Sambrook, J. \& Russell, D. (2001). Molecular Cloning: A Laboratory Manual, 3rd edn. New York: Cold Spring Habor Laboratory Press.

38. Sasaki, T., Suzaki, T., Soyano, T., Kojima, M., Sakakibara, H. \& Kawaguchi. M. (2014). Shoot-derived cytokinins systemically regulate root nodulation. Nature Communications . https://doi.org/10.1038/ncomms5983.

39. Schafer, A., Tauch, A., Jager, W., Kalinowski, J., Thierbach, G., \& Puhler, A. (1994). Small mobilizable multi-purpose cloning vectors derived from the Escherichia coli plasmids pK18 and pK19: Selection of defined deletions in the chromosome of Corynebacterium glutamicum . Gene . https://doi.org/10.1016/03781119(94)90324-7.

40. Searle, I.R., Men, A.E., Laniya, T.S., Buzas, D.M., Iturbe-Ormaetxe, M., Carroll, B.J. \& Gresshoff, P.M. (2003). Long-distance signalling in nodulation directed by a CLAVATA1-like receptor kinase. Science 
. https://doi.org/10.1126/science.1077937.

41. Shine, M.B., Xiao, X., Kachroo, P. \& Kachroo, A. (2019). Signaling mechanisms underlying systemic acquired resistance to microbial pathogens. Plant Science . https://doi.org/10.1016/j.plantsci.2018.01.001.

42. Simon, R., Priefer, U., \& Puhler, A. (1983). A broad host range mobilization system for in vivo genetic engineering: transposon mutagenesis in gram negative bacteria. Biotechnologyhttps://doi.org/10.1038/nbt1183-784.

43. Stacey, G., McAlvin, C.B., Kim, S.Y., Olivares, J. \& Soto, M.J. (2006). Effects of endogenous salicylic acid on nodulation in the model legumes Lotus japonicus and Medicago truncatula .Plant Physiology . https://doi.org/10.1104/pp.106.080986.

44. Staehelin, C. \& Krishnan, H.B. (2015). Nodulation outer proteins: double-edged swords of symbiotic rhizobia. Biochemical Journal . https://doi.org/10.1042/BJ20150518.

45. Suss, C., Hempel, J., Zehner, S., Krause, A., Patschkowski, T. \& Gottfert, M. (2006). Identification of genistein-inducible and type III-secreted proteins of Bradyrhizobium japonicum. Journal of Biotechnology . https://doi.org/10.1016/j.jbiotec.2006.03.037.

46. Terpolilli, J.J., Hood, G.A. \& Poole, P.S. (2012). What determines the efficiency of $\mathrm{N}_{2}$-fixing Rhizobium -legume symbioses? Advances in Microbial Physiology . https://doi.org/1016/B978-0-12-398264-3.00005-X.

47. Traxler, M.F., Summers, S.M., Nguyen, H.T., Zacharia, V.M., Hightower, G.A., Smith, J.T. \& Conway, T. (2008). The global, ppGpp-mediated stringent response to amino acid starvation inEscherichia coli . Molecular Microbiology . https://doi.org/10.1111/j.1365-2958.2008.06229.

48. Tsukui, T., Eda, S., Kaneko, T., Sato, S., Okazaki, S., Kakizaki-Chiba, K., Itakura, M., Mitsui. H., Yamashita, A., Terasawa, K. \& Minamisawa, K. (2013). The type III Secretion System ofBradyrhizobium japonicum USDA122 mediates symbiotic incompatibility with Rj2 soybean plants. Applied and Environmental Microbiology . https://doi.org/10.1128/AEM.03297-12.

49. Turgeon, B.G. \& Bauer, W.D. 1985. Ultrastructure of infection-thread development during the infection of soybean by Rhizobium japonicum . Plantahttps://doi.org/10.1007/BF00395142.

50. Velasquez, S.M., Barbez, E., Kleine-Vehn, J. \& Estevez. J.M. (2016). Auxin and cellular elongation. Plant Physiology . https://doi.org/10.1104/pp.15.01863.

51. Vieira, J. \& Messing, J. (1982). The pUC plasmids, an M13mp7-derived system for insertion mutagenesis and sequencing with synthetic universal primers. Gene . https://doi.org/10.1016/0378-1119(82)90015-4.

52. Vincent, J. (1970). A Manual for the practical study of the root-nodule bacteria. Oxford: Blackwell Scientific Publ. https://doi.org/10.1002/jobm.19720120524.

53. Vogels, G. D. \& van der Drift, C. (1970). Differential analysis of glyoxylate derivatives. Analytical Biochemistry . https://doi.org/10.1016/0003-269770)90448-3

54. Wang,. L., Sun, Z., Su, C., Wang, Y., Yan, Q., Chen, J., Ott, T. \& Li, X. (2019). A GmNINa miR172 - -NNC1 regulatory network coordinates the nodulation and autoregulation of nodulation pathways in soybean. Molecular Plant . https://doi.org/10.1016/j.molp.2019.06.002.

55. Wells, D.H. \& Gaynor, E.C. (2006). Helicobacter pyloriinitiates the stringent response upon nutrient and $\mathrm{pH}$ downshift.Journal of Bacteriology . https://doi.org/10.1128/JB.188.10.3726-3729.2006.

56. Wells, D.H., \& Long, S.R. (2002). The Sinorhizobium melilotistringent response affects multiple aspects of symbiosis. Molecular Microbiology . https://doi.org/10.1046/j.1365-2958.2002.02826.x.

57. Wippel, K. \& Long, S.R. (2016). Contributions ofSinorhizobium meliloti transcriptional regulator DksA to bacterial growth and efficient symbiosis with Medicago sativa. Journal of Bacteriology . https://doi.org/10.1128/JB.00013-16. 
58. Wippel, K. \& Long, S.R. (2019). Symbiotic performance ofSinorhizobium meliloti lacking ppGpp depends on theMedicago host species. Molecular Plant Microbe Interactions . https://doi.org/10.1094/MPMI-11-180306-R.

\section{TABLES}

TABLE 1. Fold-change expression of selected genes from the B. diazoefficiens T3SS in starving cultures, under genistein-i

\begin{tabular}{l} 
Gene \\
$t$ ttsI \\
rhcJ \\
${ }^{+}$Induction was performed with $2 \mu \mathrm{M}$ genistein in starving medium. The housekeeping gene sigA was used as internal contr \\
\hline
\end{tabular}

\begin{tabular}{|c|c|c|c|c|c|}
\hline $\begin{array}{l}\text { TABLE } 2 . \\
\text { Relative } \\
\text { expression }{ }^{+} \text {of } \\
\text { genes encoding }\end{array}$ & $\begin{array}{l}\text { TABLE } 2 . \\
\text { Relative } \\
\text { expression }^{+} \text {of } \\
\text { genes encoding }\end{array}$ & $\begin{array}{l}\text { TABLE } 2 . \\
\text { Relative } \\
\text { expression }^{+} \text {of } \\
\text { genes encoding }\end{array}$ & $\begin{array}{l}\text { TABLE } 2 . \\
\text { Relative } \\
\text { expression }^{+} \text {of } \\
\text { genes encoding }\end{array}$ & $\begin{array}{l}\text { TABLE } 2 . \\
\text { Relative } \\
\text { expression }{ }^{+} \text {of } \\
\text { genes encoding }\end{array}$ & $\begin{array}{l}\text { TABLE } 2 . \\
\text { Relative } \\
\text { expression }^{+} \text {of } \\
\text { genes encoding }\end{array}$ \\
\hline $\begin{array}{l}\text { CLE peptides } \\
\text { in soybeans }\end{array}$ & $\begin{array}{l}\text { CLE peptides } \\
\text { in soybeans }\end{array}$ & $\begin{array}{l}\text { CLE peptides } \\
\text { in soybeans }\end{array}$ & $\begin{array}{l}\text { CLE peptides } \\
\text { in soybeans }\end{array}$ & $\begin{array}{l}\text { CLE peptides } \\
\text { in soybeans }\end{array}$ & $\begin{array}{l}\text { CLE peptides } \\
\text { in soybeans }\end{array}$ \\
\hline inoculated & inoculated & inoculated & inoculated & inoculated & inoculated \\
\hline with $B$. & $\begin{array}{l}\text { with } B . \\
\text { diazoefficiens }\end{array}$ & with $B$. & with $B$. & with $B$. & with $B$. \\
\hline $\begin{array}{l}\text { aıаzоеллсепs } \\
\text { USDA } 110\end{array}$ & $\begin{array}{l}\text { arazoeffcrens } \\
\text { USDA } 110\end{array}$ & USDA 110 & USDA 110 & USDA 110 & USDA 110 \\
\hline (wild-type) or & (wild-type) or & (wild-type) or & (wild-type) or & (wild-type) or & (wild-type) or \\
\hline $\begin{array}{l}\text { its } r s h \text { mutant } \\
\text { derivative. }\end{array}$ & $\begin{array}{l}\text { its } r s h \text { mutant } \\
\text { derivative. }\end{array}$ & $\begin{array}{l}\text { its } r s h \text { mutant } \\
\text { derivative. }\end{array}$ & $\begin{array}{l}\text { its } r s h \text { mutant } \\
\text { derivative. }\end{array}$ & $\begin{array}{l}\text { its } r s h \text { mutant } \\
\text { derivative. }\end{array}$ & $\begin{array}{l}\text { its } r s h \text { mutant } \\
\text { derivative. }\end{array}$ \\
\hline $\begin{array}{l}\text { The plants } \\
\text { were }\end{array}$ & $\begin{array}{l}\text { The plants } \\
\text { were }\end{array}$ & $\begin{array}{l}\text { The plants } \\
\text { were }\end{array}$ & $\begin{array}{l}\text { The plants } \\
\text { were }\end{array}$ & $\begin{array}{l}\text { The plants } \\
\text { were }\end{array}$ & $\begin{array}{l}\text { The plants } \\
\text { were }\end{array}$ \\
\hline cultivated in & cultivated in & cultivated in & cultivated in & cultivated in & cultivated in \\
\hline $\begin{array}{l}\text { either N-free } \\
\text { plant nutrient }\end{array}$ & $\begin{array}{l}\text { either N-free } \\
\text { plant nutrient }\end{array}$ & $\begin{array}{l}\text { either N-free } \\
\text { plant nutrient }\end{array}$ & $\begin{array}{l}\text { either N-free } \\
\text { plant nutrient }\end{array}$ & $\begin{array}{l}\text { either N-free } \\
\text { plant nutrient }\end{array}$ & $\begin{array}{l}\text { either N-free } \\
\text { plant nutrient }\end{array}$ \\
\hline solution or & solution or & solution or & solution or & solution or & solution or \\
\hline $\begin{array}{l}\text { plant nutrient } \\
\text { solution }\end{array}$ & $\begin{array}{l}\text { plant nutrient } \\
\text { solution }\end{array}$ & $\begin{array}{l}\text { plant nutrient } \\
\text { solution }\end{array}$ & $\begin{array}{l}\text { plant nutrient } \\
\text { solution }\end{array}$ & $\begin{array}{l}\text { plant nutrient } \\
\text { solution }\end{array}$ & $\begin{array}{l}\text { plant nutrient } \\
\text { solution }\end{array}$ \\
\hline supplemented & supplemented & supplemented & supplemented & supplemented & supplemented \\
\hline with 10 mM & with $10 \mathrm{mM}$ & with 10 mM & with 10 mM & with 10 mM & with $10 \mathrm{mM}$ \\
\hline \multirow{3}{*}{$\mathrm{NH}_{4} \mathrm{NO}_{3}^{++}$} & $\mathrm{NH}_{4} \mathrm{NO}_{3}{ }^{++}$. & $\mathrm{NH}_{4} \mathrm{NO}_{3}{ }^{++}$. & $\mathrm{NH}_{4} \mathrm{NO}_{3}{ }^{++}$. & $\mathrm{NH}_{4} \mathrm{NO}_{3}{ }^{++}$. & $\mathrm{NH}_{4} \mathrm{NO}_{3}{ }^{++}$ \\
\hline & $10 \mathrm{mM}$ & $10 \mathrm{mM}$ & & $r s h$ & $r s h$ \\
\hline & $\begin{array}{l}\mathrm{NH}_{4} \mathrm{NO}_{3} / \mathrm{N}- \\
\text { free }\end{array}$ & $\begin{array}{l}\mathrm{NH}_{4} \mathrm{NO}_{3} / \mathrm{N}- \\
\text { free }\end{array}$ & & $\begin{array}{l}\text { mutant/wild- } \\
\text { type }\end{array}$ & $\begin{array}{l}\text { mutant/wild- } \\
\text { type }\end{array}$ \\
\hline \multirow[t]{2}{*}{ Gene } & wild type & rsh mutant & & N-free & $10 \mathrm{mM}$ \\
\hline & & & & & $\mathrm{NH}_{4} \mathrm{NO}_{3}$ \\
\hline \multirow[t]{2}{*}{ GmNIC1 } & $251.14 \pm 36.65$ & $338.41 \pm$ & & $2,90 \pm 1.08 \mathrm{~A}$ & $3.27 \pm 0.55 \mathrm{~A}$ \\
\hline & A & $116.60 \mathrm{~A}$ & & & \\
\hline GmRIC1 & $-7.38 \pm 3.19 \mathrm{~A}$ & $\begin{array}{l}-13.10 \pm 4.29 \\
\mathrm{~A}\end{array}$ & & $3.41 \pm 2.95 \mathrm{~A}$ & $-3,34 \pm 2.93 \mathrm{~B}$ \\
\hline GmRIC2 & $-6.33 \pm 4.79 \mathrm{~A}$ & $-3.03 \pm 2.63 \mathrm{~A}$ & & $3.21 \pm 0.93 \mathrm{~A}$ & $-1.79 \pm 0.90 \mathrm{~B}$ \\
\hline
\end{tabular}




\begin{tabular}{|c|c|c|c|c|c|}
\hline $\begin{array}{l}\text { TABLE } 2 . \\
\text { Relative } \\
\text { expression }{ }^{+} \text {of } \\
\text { genes encoding }\end{array}$ & $\begin{array}{l}\text { TABLE } 2 . \\
\text { Relative } \\
\text { expression }^{+} \text {of } \\
\text { genes encoding }\end{array}$ & $\begin{array}{l}\text { TABLE } 2 . \\
\text { Relative } \\
\text { expression }^{+} \text {of } \\
\text { genes encoding }\end{array}$ & $\begin{array}{l}\text { TABLE } 2 . \\
\text { Relative } \\
\text { expression }^{+} \text {of } \\
\text { genes encoding }\end{array}$ & $\begin{array}{l}\text { TABLE } 2 . \\
\text { Relative } \\
\text { expression }^{+} \text {of } \\
\text { genes encoding }\end{array}$ & $\begin{array}{l}\text { TABLE } 2 . \\
\text { Relative } \\
\text { expression }{ }^{+} \text {of } \\
\text { genes encoding }\end{array}$ \\
\hline CLE peptides & CLE peptides & CLE peptides & CLE peptides & CLE peptides & CLE peptides \\
\hline in soybeans & in soybeans & in soybeans & in soybeans & in soybeans & in soybeans \\
\hline inoculated & inoculated & inoculated & inoculated & inoculated & inoculated \\
\hline with $B$. & with $B$ & with $B$ & with $B$ & with $B$. & with $B$. \\
\hline diazoefficiens & diazoefficiens & diazoefficiens & diazoefficiens & diazoefficiens & diazoefficiens \\
\hline USDA 110 & USDA 110 & USDA 110 & USDA 110 & USDA 110 & USDA 110 \\
\hline (wild-type) or & (wild-type) or & (wild-type) or & (wild-type) or & (wild-type) or & (wild-type) or \\
\hline $\begin{array}{l}\text { its } r s h \text { mutant } \\
\text { derivative. }\end{array}$ & $\begin{array}{l}\text { its } r s h \text { mutant } \\
\text { derivative. }\end{array}$ & $\begin{array}{l}\text { its } r s h \text { mutant } \\
\text { derivative. }\end{array}$ & $\begin{array}{l}\text { its } r s h \text { mutant } \\
\text { derivative. }\end{array}$ & $\begin{array}{l}\text { its } r s h \text { mutant } \\
\text { derivative. }\end{array}$ & $\begin{array}{l}\text { its } r s h \text { mutant } \\
\text { derivative. }\end{array}$ \\
\hline $\begin{array}{l}\text { The plants } \\
\text { were }\end{array}$ & $\begin{array}{l}\text { The plants } \\
\text { were }\end{array}$ & $\begin{array}{l}\text { The plants } \\
\text { were }\end{array}$ & $\begin{array}{l}\text { The plants } \\
\text { were }\end{array}$ & $\begin{array}{l}\text { The plants } \\
\text { were }\end{array}$ & $\begin{array}{l}\text { The plants } \\
\text { were }\end{array}$ \\
\hline cultivated in & cultivated in & cultivated in & cultivated in & cultivated in & cultivated in \\
\hline either N-free & either N-free & either N-free & either N-free & either N-free & either N-free \\
\hline plant nutrient & plant nutrient & plant nutrient & plant nutrient & plant nutrient & plant nutrient \\
\hline solution or & solution or & solution or & solution or & solution or & solution or \\
\hline $\begin{array}{l}\text { plant nutrient } \\
\text { solution }\end{array}$ & $\begin{array}{l}\text { plant nutrient } \\
\text { solution }\end{array}$ & $\begin{array}{l}\text { plant nutrient } \\
\text { solution }\end{array}$ & $\begin{array}{l}\text { plant nutrient } \\
\text { solution }\end{array}$ & $\begin{array}{l}\text { plant nutrient } \\
\text { solution }\end{array}$ & $\begin{array}{l}\text { plant nutrient } \\
\text { solution }\end{array}$ \\
\hline supplemented & supplemented & supplemented & supplemented & supplemented & supplemented \\
\hline with $10 \mathrm{mM}$ & with $10 \mathrm{mM}$ & with $10 \mathrm{mM}$ & with $10 \mathrm{mM}$ & with $10 \mathrm{mM}$ & with $10 \mathrm{mM}$ \\
\hline $\mathrm{NH}_{4} \mathrm{NO}_{3}{ }^{++}$ & $\mathrm{NH}_{4} \mathrm{NO}_{3}{ }^{++}$ & $\mathrm{NH}_{4} \mathrm{NO}_{3}{ }^{++}$. & $\mathrm{NH}_{4} \mathrm{NO}_{3}{ }^{++}$ & $\mathrm{NH}_{4} \mathrm{NO}_{3}{ }^{++}$ & $\mathrm{NH}_{4} \mathrm{NO}_{3}{ }^{++}$. \\
\hline${ }^{+}$The & ${ }^{+}$The & ${ }^{+}$The & ${ }^{+}$The & ${ }^{+}$The & ${ }^{+}$The \\
\hline housekeeping & housekeeping & housekeeping & housekeeping & housekeeping & housekeeping \\
\hline gene $G m E F 1$ & gene $G m E F 1$ & gene $G m E F 1$ & gene $G m E F 1$ & gene $G m E F 1$ & gene $G m E F 1$ \\
\hline was used as & was used as & was used as & was used as & was used as & was used as \\
\hline internal & internal & internal & internal & internal & internal \\
\hline control. & control. & control. & control. & control. & control. \\
\hline++ Values are & ${ }^{++}$Values are & ${ }^{++}$Values are & ${ }^{++}$Values are & ${ }^{++}$Values are & ${ }^{++}$Values are \\
\hline SE from three & from three & from three & from three & from three & from three \\
\hline independent & independent & independent & independent & independent & independent \\
\hline experiments. & experiments. & experiments. & experiments. & experiments. & experiments. \\
\hline Statistical & Statistical & Statistical & Statistical & Statistical & Statistical \\
\hline $\begin{array}{l}\text { analysis was } \\
\text { performed by }\end{array}$ & analysis was & analysis was & analysis was & analysis was & analysis was \\
\hline $\begin{array}{l}\text { performed by } \\
\text { ANOVA }\end{array}$ & performed by & performed by & performed by & performed by & perforn \\
\hline & & & & & ANOV \\
\hline followed by & followed by & followed by & followed by & followed by & followed by \\
\hline Tukey test. & Tukey test. & Tukey test. & Tukey test. & Tukey test. & Tukey test. \\
\hline Values & Values & Values & Values & Values & Values \\
\hline followed by & followed by & followed by & followed by & followed by & followed by \\
\hline different & different & different & different & different & different \\
\hline letters in the & letters in the & letters in the & letters in the & letters in the & letters in the \\
\hline same row are & same row are & same row are & same row are & same row are & same row are \\
\hline significantly & significantly & significantly & significantly & significantly & significantly \\
\hline different $(p<$ & different $(p<$ & different $(p<$ & different $(p<$ & different $(p<$ & different $(p<$ \\
\hline 0.05$)$ & $0.05)$ & $0.05)$ & $0.05)$ & $0.05)$ & $0.05)$ \\
\hline
\end{tabular}


TABLE 3. Symbiotic parameters from soybean plants inoculated with $B$. diazoefficiens USDA 110 (wild-type) or its $r s h n$

\author{
Parameter \\ Nodules per plant \\ Nodule dry weight (mg) \\ Shoot dry weight $(\mathrm{g})$ \\ Ureides ( $\mu$ mol g-1 leaf dry weight) \\ Nodules occupation in competition $(\%)^{++}$ \\ ${ }^{+}$Values are average \pm SE from three independent experiments. Statistical analysis was performed by ANOVA followed by ${ }^{\prime}$
}

\title{
FIGURE LEGENDS
}

FIGURE 1. Scheme of $r s h$ and its mutant derivative.A : domains predicted with BLASTP. B : Comparison of the wild-type (upper row) and insertional mutant (lower row) rsh fromB. diazoefficiens . The position and directions of the primers used to obtain the mutation and validate it are indicated by green arrows. The sizes of the fragments used for the mutation are indicated below the blue lines. The insertion occurred between the XhoI sites at bases 5,619,575 and 5,619,590, in reverse orientation.

FIGURE 2. Growth and survival of B. diazoefficiens USDA 110 (wild-type) and its rsh mutant derivative. A : Total biomass, evaluated by optical density at $500 \mathrm{~nm}\left(\mathrm{OD}_{500}\right)$ in PSY. B : Remnant viable bacteria (as colony-forming units, CFU) from a suspension in MOPS shaked at $28 \mathrm{degC}$ after the indicated times.

FIGURE 3 . SAR response in soybean. A : Relative expression of the SAR marker GmPR1 in the rsh mutant with respect to the wild-type (fold-change). Values are average +- SD from three independent experiments. GmEF1 was used as internal constitutive control. B : Reactive oxygen species (ROS) measured in the root hair tips of soybean plants with a $\mathrm{H}_{2}$ DCF-DA probe. The plants were inoculated with $B$. diazoefficiens USDA 110 (wild-type) or its rsh mutant derivative, and cultivated for four days. As controls, a group of plants were kept without inoculation. Dots are individual fluorescence intensity measures, and horizontal lines indicate the median (longer line) or the first and third quartiles (shorter lines). Significance of the differences between wild-type and $r s h$ mutant strains are indicated as follows: NS: non-significant $(p>0.05)$; **: significant $(p$ $<0.01)$. Each point corresponds to one root hair. Data were collected from three independent experiments each one with, at least, four different plants for each condition. hpi: hours post-inoculation.

FIGURE 4. Nodules from soybean inoculated with B. diazoefficiens USDA 110 in the absence (A , B ,E , $\mathbf{F}$ ) or the presence $(\mathbf{C}, \mathbf{D}, \mathbf{G}, \mathbf{H})$ of $10 \mathrm{mM} \mathrm{NH}_{4} \mathrm{NO}_{3}$. The wild-type $(\mathbf{A}, \mathbf{C}, \mathbf{E}, \mathbf{G})$ and itsrsh mutant derivative (B, D , F , G ) are compared. Entire nodules were viewed under a stereomicroscope (A -D ). Ultrathin cuts from these nodules were observed with a transmission electron microscope $(\mathbf{E}-\mathbf{H})$.

FIGURE 5. Auxins released to the culture medium by B. diazoefficiens USDA 110 (wild-type) or its rsh mutant derivative. Auxins were measured by a colorimetric method using indoleacetic acid (IAA) as standard. Error bars indicate SD. Statistical analysis was carried out by ANOVA (****: significant difference with $p<$ $0.0001)$.

FIGURE 6. Proposed role of the stringent response on AON, according to the results obtained in this work (thick lines) and others from the literature (thin lines). Dashed lines indicate that correlations were observed, but direct relations were not proved. To underscore this, the central question mark indicates that there might be either an unidentified intermediate process, or no intermediate. For further details, see the text.

\section{SUPPORTING INFORMATION}

TABLE S1 Primers used in this study

FIGURE S1 Genomic context of relA and spotanalogs.

FIGURE S2 Domains structure of various $r s h$, relAor spot analogs from different species. 


\section{Hosted file}

Perez-Gimenez Figure 1.pptx available at https://authorea.com/users/346891/articles/472705a-stringent-response-defective-bradyrhizobium-diazoefficiens-mutant-elicits-early-plantdefense-and-modifies-autoregulation-of-nodulation-in-soybean

\section{Hosted file}

Perez-Gimenez Figure 2.pptx available at https://authorea.com/users/346891/articles/472705a-stringent-response-defective-bradyrhizobium-diazoefficiens-mutant-elicits-early-plantdefense-and-modifies-autoregulation-of-nodulation-in-soybean

\section{Hosted file}

Perez-Gimenez Figure 3.pptx available at https://authorea.com/users/346891/articles/472705a-stringent-response-defective-bradyrhizobium-diazoefficiens-mutant-elicits-early-plantdefense-and-modifies-autoregulation-of-nodulation-in-soybean

\section{Hosted file}

Perez-Gimenez Figure 4.pptx available at https://authorea.com/users/346891/articles/472705a-stringent-response-defective-bradyrhizobium-diazoefficiens-mutant-elicits-early-plantdefense-and-modifies-autoregulation-of-nodulation-in-soybean

\section{Hosted file}

Perez-Gimenez Figure 5.pptx available at https://authorea.com/users/346891/articles/472705a-stringent-response-defective-bradyrhizobium-diazoefficiens-mutant-elicits-early-plantdefense-and-modifies-autoregulation-of-nodulation-in-soybean

\section{Hosted file}

Perez-Gimenez Figure 6.pptx available at https://authorea.com/users/346891/articles/472705a-stringent-response-defective-bradyrhizobium-diazoefficiens-mutant-elicits-early-plantdefense-and-modifies-autoregulation-of-nodulation-in-soybean 